\title{
Knowledge Management: The Key to Sustainability of Economic Crisis
}

\section{Phd Candidate Luftim Cania}

European University of Tirana, Email: luftimcania@yahoo.com

\section{Prof. Assos. Dr. Bajram Korsita}

University "Aleksander Moisiu", Durres Email: bajramkorsita@yahoo.com

\section{Doi:10.5901/mjss.2015.v6n1s1p548}

\begin{abstract}
Today, crises occur everywhere. One of the recent crises was the economic crisis which began in 2008. Crises carry the element of uncertainty and complexity. Crisis situations need for planning, organizing, directing and monitoring organizations experiencing difficulties that directly threaten their existence. Despite the nature of their occurrence they return to crisis management, which must be managed carefully by using the institution's organizational resources. One of the most valuable resources is knowledge. Knowledge management in the organization will enable the identification of critical information about the situation of the crisis and its management to cope with the crisis and to become competitive. An organization during the crisis if it arrives better manage its knowledge, will then enable coping with the crisis. Also, the organization will have more opportunity to revive by crises. The aim of this study is to examine the importance of knowledge management during periods of crisis in order to confront it successfully. This study is based on the receipt, collection and analysis of data from various studies about this field. Knowledge management plays an important role to successfully cope with crisis situations. It is an effective tool.
\end{abstract}

Keywords: knowledge management, crisis, management leadership.

\section{Introduction}

Crises are everywhere today. Even one such crisis was the global financial crisis that began in 2008, led to the increasing difficulty and complexity of securing sufficient competitiveness. They are often surrounded by a complex of various complex factors. By their nature, crises are related to the uncertainty element. This fact is focus to our environment. It is becoming increasingly complex always creating problems. Therefore the development of various crises are becoming an integral part of modern business is not at all surprising. However, the resolution of a crisis situation and prevent it in this way require reorganization of the company which often can only be achieved through radical modification methods. A crisis in the company can be defined as a short-term, unwanted, adverse which directly threatens the further existence and growth of the company. Crisis situations need for planning, organizing, directing and monitoring organizations experiencing difficulties that directly threaten their existence. Also further development of the organization in order to prevent negative effects, achieving a drastic change and providing the basis for redevelopment. Also instrumental in these crisis situations require rapid decision making which should be as right as possible, because corrections are usually not possible. Pressure of time and the decision is against the causes and course of the formation of the crisis, which is usually a longer period.

Faced with these dilemmas, managers will expect to be familiar with the crisis, or at least have access to its approximate knowledge. They need to recognize the crisis details. Different experts describe today's global economy as a transformation right knowledge economy. Information systems and information technology have been made in the early $21^{\text {th }}$ century the most important factors for the economy. This has to do with the use of technology and information in a new managerial approach. These changes are reflected in the current economy. The capital strategic human resource organizations are based on knowledge. The organizations can cope with the crisis and to become competitive.

Bhatt (2001) claims KM shapes the interaction pattern between technologies, techniques, and people. However, that exclusive focus on people, technologies, or techniques does not enable a firm to sustain its competitive advantages. It is, rather, the interaction between technologies, techniques, and people that allow an organization to manage its 
knowledge effectively. By creating a nurturing and "learning-by-doing" kind of environment, an organization can sustain its competitive advantages (Bhatt, 2001).

Referring to the above changes and events rapidly, the aim to this study is to examine the importance of knowledge management during periods of crisis in order to confront it successfully. The main objectives of the study are:

a. To observe the role of knowledge management during periods of crisis.

b. To observe the role of managerial leadership in the creation of knowledge in the organization and through that tackling the crisis.

\section{Literature Review}

As defined by Davenport and Prusak (1998), knowledge is a fluid mix of framed experience, values, contextual information, expert insight and grounded intuition that provides an environment and framework for evaluating and incorporating new experiences and information. It originates and is applied in the mind of knower. In organizations, it often becomes embedded not only in documents or repositories but also in organizational routines, processes, practices and processes. According Gupta and Govindarajan (2000) Knowledge Management (KM) is a process that helps organizations finding, select, organize, disseminate, and transfer important information and expertise necessary for activities. In addition, Grey (1999) defines knowledge management as a process involving identification of critical information, sharing of information, protecting and enhancing the value of information, and leveraging knowledge utility in major organizational level decisions. Also, Bhatt (2001) KM is a process of knowledge creation, validation, presentation, distribution and application. In another way, Knowledge Management is to discover, develop, utilize, deliver, and absorb knowledge inside and outside the organization through an appropriate management process to meet current and future needs (Ouintas, Lefrere and Jones, 1997). However, Tiwana (2002) argued that knowledge management is the management of organizational knowledge for creating business value and generating a competitive advantage and it enables the creation, communication, and application of knowledge of all kinds to achieve business goals.

The various economic crises, financial or different natures of crisis risk the normal performance of organizations. These crises are out the plans and forecasts that the organization has made. These crisis return to crisis management and is necessarily to management them. MacNeil and Topping (2007) defined a crisis as an event that causes severe emotional and social distress, which may occur at any time and without warning. Similarly, Winkleman (1999) explained that a crisis is an unexpected event that threatens organizations' function and existence. Crisis management entails forecasting, identifying, studying and acting upon crisis issues, and establishing procedures that would enable an organization to prevent or cope with crises (Nurmi and Darling, 1997).

During various economic crises or management is needed to apply knowledge management. Organization must reproduce the new plans, despite plans that have projected before the crisis, crisis being adapted. Quarantelli (1988) contends that there exists a gap between what people have planned for and what they really encounter in a crisis. This implies the need for organizations to figure out what knowledge they really need to know in order to be better prepared for dealing with potential crises. Darling (1994) argues that organizations should capitalize on the expertise of individuals from various operational areas in order to use their expertise to plan for and manage the crisis. This argument implies the need to create a certain kind of knowledge repository to store knowledge of employees. Lagadec (1997) argues that one of the major challenges in crisis management is to rapidly identify experts who have particular kinds of knowledge and present this knowledge to employees who directly deal with crises before it is too late. Simon and Pauchant (2000) argue that organizations should increase their knowledge bases by creating knowledge about potential crises by learning from the experience gained from crises, which in turn can enhance organization's capability of coping with similar crises. Managing knowledge well is the key to enhance an organization's ability to deal with business crises.

Planning for a crisis, as a turning point, is the art of removing much of the risk in uncertainty, thereby allowing those concerned to achieve more control over the destiny of an organization, and thus creatively exercising the role of management leadership (Darling, Shelton and Walker, 2002).

\section{The Methodology}

The research method to this study is achieved through collection and analysis of various publications about this field. This study is focused on the various publications that have been made in this area about empirical studies, various academic debates and analyzes the different findings. The reason for the use of this methodology is to analyze the different findings and to observe how important are knowledge management during periods of crisis. These publications have been published in various journals, conferences, and through books. The major focus is placed on publications in various 
journals for a period of two decades.

\section{The Role of Knowledge Management}

The basic duties of managing a company during crisis are to stop negative performance and to provide the basis for new development. An organization during the crisis will be faced with an opportunity to revive and requires an approach for its management during and after the crisis. Due to the constant pressure of time for decision-making, limiting the different tools available and trends of short-term solutions mainly operational problems, crisis management should use appropriate methods and techniques to manage the crisis.

Knowledge is one of the most important sources of competitive advantage (Hitt, Bierman, Shimizu and Kochhar, 2001). According to the knowledge-based view of the firm, sustainable competitive advantage is based on exploiting, exploring and retaining a firm's knowledge (Grant, 1996). Nevertheless, knowledge retention is a core element of the organizational memory concept, enabling firms to embed knowledge within the organization (Argote, McEvily and Reagans, 2003). This knowledge is retained in various 'human' and 'non-human' repositories on specific organizational levels (Walsh and Ungson, 1991). However, the organizational knowledge retained through employees-also defined as human capital-is the most valuable source of competitive advantage (Grant, 1996). This retained knowledge is an integral part of the organizational learning process (Olivera, 2000).

Fast changes in the environment with unforeseen consequences call for a redirection of crisis management that has been traditionally focused on plans and procedures, the learning and development of flexible options for recovery in unforeseen crises (Acquier, Gand \& Szpirglas, 2008). During a crisis the members of the organization must create new mental models in order to adapt themselves to a crisis situation and at the same time find new ways for the integration of their individual mental models that will allow coordinated activities (Roberts, Madsen \& Desai, 2007). So, Weick's (1995) refers four-level framework is a good starting point to analyze how critical knowledge can be retained throughout an organization. On the first level (individual or intra subjective level), individuals store their knowledge of specific causeand-effect relationships, creating an individual frame of reference. Interactions between individuals create the second, inter subjective, level: a universal reliable frame of reference creating shared meaning between individuals and groups. These inter subjective frames of reference create a 'collective mind' (Weick and Roberts, 1993). On the third, collective level, these inter subjective frames are stored and preserved over time (in job categories, routines, ideologies, etc.), resulting in retained organizational knowledge. The final, extra subjective, level retains knowledge on a macro level, such as in organizational culture and institutional arte facts (Weick, 1995).

\section{Strategic Approach of KM in Crisis}

The knowledge economy is dynamic, with potential competitive threats coming from rapid technological advances that disrupt existing business models (Hitt, Keats, \& DeMarie, 1998). By this approach, today organizations consider knowledge as a strategic lever for the competitive advantage and their business success seems to depend increasingly on the ability to assess, manage and develop their own knowledge as well as to acquire new knowledge (Davenport and Prusak, 1998). Proponents of a knowledge-based approach to competitive advantage argue that the primary purpose of a firm is to create and apply knowledge (DeCarolis \& Deeds, 1999). According to Teece (1998), the competitive advantage of companies in today's economy stems not from market position, but from difficult to replicate knowledge assets and the manner in which they are deployed. In fact, effective implementation of KM needs a combination of aspects of strategic, managerial and operational. KM contributes to the competitiveness of the company for as long as it is a direct link with organization strategy. An organization might select highly conscientious individuals or train a team to develop more collectivist values, but neither of these routes would lead to sustained competitive advantage. Competitive advantage is gained only when the organization selects or develops the needed resources and structures work tasks and the reward system in ways that motivate the team to perform well and thereby contribute to organizational effectiveness (Guzzo \& Shea, 1992). Team effectiveness may be enhanced through selection and training, but competitive advantage comes only when the organization structures rewards and work to leverage those effective teams to improve organizational performance (Jackson \& Schuler, 2003).

Evans (2003) and Tiwana (2002) also suggest that knowledge is the most important resource of a firm. Evans (2003) pointed out that material resources decrease when used in the firm, while knowledge assets increase with use. Tiwana (2002) argued that technology, capital, market share or product sources are easier to copy by other firms while knowledge is the only resource that is difficult to imitate. Zack (1999) divides organizational knowledge into three categories: core knowledge, advanced knowledge, and innovative knowledge. Core knowledge is the basic knowledge 
that enables a firm to survive in the market in the short-term. Advanced knowledge provides the firm with similar knowledge as its rivals and allows the firm to actively complete in the short term. Innovative knowledge gives the firm its competitive position over its rivals. The firm with innovative knowledge is able to introduce innovative products or services, potentially helping it become a market leader (Zack 1999).

\section{Role of Management Leadership}

To be successful today with this intense crisis, organizational management should develop and establish new skills. These skills must be in harmony with the prospect of business organizations as human systems that are based basically rolled into one, interactive, highly variable able to work systematically, rather than, stable operations-like machine. The basic principles of quantum mechanics and relationships provide meaningful insights into a world that is objective and subjective, logical and irrational, linear and nonlinear, orderly and chaotic; and a world in which the process of observation somehow affects that which is observed (Shelton and Darling, 2001).

Organizational crises are described as low-probability and high-consequence events and are generally characterized by ambiguity (Pearson \& Clair, 1998). The effective management of an organizational crisis is dependent on leadership behavior that encourages members to actively engage in knowledge acquisition and the formulation of strategies to resolve the crisis (Wooten \& James, 2004). As business environments change and grow increasingly complex, it is particularly important that leaders develop a set of skills that will help them prevent and effectively respond to crisis and other strategic issues (Garcia, 2006). It is through the development and implementation of meaningful leadership strategies that effective crisis management becomes a reality for a business firm. In this regard, there is a profound difference between management and leadership, but one should readily recognize that both are important (Darling, McKenna and Walker, 2002). The distinction is crucial when it comes to successful crisis management, particularly across cultural boundaries. Managers are people who do things right, and leaders are people who do the right things.

In a volatile environment such as a crisis situation, HRD activities can contribute to the success of its organization by harnessing and developing employees (McCracken \& Wallace, 2000). This is accomplished through a strategic partnership, where the HRD activities are proactively aligned with the goals of the organization's overall strategy in generals, and crisis management plan in particular (Garavan, 1991). These HRD alignment activities can include environmental scanning for opportunities and threats, developing crisis management policies and procedures, working with line management on operational issues, and fostering a learning culture (Ruona, Lynham, \& Chermack, 2003). Behaviors such as sense making, managing the change process, taking risks, and fostering organizational agility during a crisis may take a back seat to managing the ostensibly more pressing matters associated with communication and public relations (James \& Wooten, 2005). Moreover, when powers are appropriate to the organization's work, the likelihood that the firm will be resilient after the crisis has increased greatly. Leadership crisis requires an integration of skills and traits that allow a leader to plan for, respond to, and learn from the events of the crisis, while under public scrutiny.

\section{Conclusions}

Today crises are everywhere. A recent crisis was the financial crisis that emerged in 2008. The development of various crises has become an integral part of modern business. The organizations must find appropriate ways and methods how to cope with this crisis. So, the crisis situations need to plan, to organize, to run and to survey continuously. Managers need to be prudent in their decisions during these situations. A prudent decision to give the organization can benefit by becoming competitive. An effective tool during this situation is knowledge management. During situations of crisis, it is necessary to apply the knowledge management. According to various authors, knowledge management related to a process that identifies critical information, selects, organizes, distributes and uses information in the required activities. Planning during a crisis is a risky art unsafe to run the organization. The knowledge management role is essential in the organization, especially during periods of crisis. It makes possible to cope with the crisis and serves as a source of competitive advantage. Today's economy based on knowledge is dynamic competitive potentials generated by rapid changes in the external environment. Competitive advantages for companies today do not refer to positions in the market, but based on knowledge assets. Organizations can have many skilled employees but if these employees do not possess the required knowledge, then loses organizations struggle to be competitive. Thus, management leadership plays an important role to develop required knowledge. These insights are necessary to integrate with the organization's strategic priorities. Effective management of an organization during the crisis period will depend on the behavior of managers and knowledge that will apply or have applied. 


\section{References}

Acquier, A., Gand, S., \& Szpirglas, M. (2008). From Stakeholder to StakeSholder Management in Crisis Episodes: A case study in a public transportation company. Journal of Contingencies and Crisis Management, 101-114.

Argote, L., McEvily, B., and Reagans, R., (2003). Managing knowledge in organizations: An integrative framework and review of emerging themes. Management Science, 49 (4), 571-582.

Bhatt, G.D., (2001). Knowledge management in organizations: examining the interaction between technologies, techniques, and people. Journal of Knowledge Management, 5 (1), 68-75.

Decarolis, D. M., and Deeds, D. L., (1999). The Impact of Stocks and Flows of Organizational Knowledge on Firm Performance: An Empirical Investigation of the Biotechnology Industry. Strategic Management Journal, (20), 953-968.

Darling, J. R., (1994). Crisis Management in International Business: Keys to Effective Decision Making. Leadership and Organization Development Journal, Fall, 3-8.

Darling, J. R., Mckenna, M. K., and Walker, W.E., (2002). Keys to Organizational Excellence: Leadership Values and Strategies. Journal of Business and Society, Spring, 132-147.

Darling, J. R., Shelton, C. K., and Walker, W. E., (2002). Foundations of Organizational Excellence: Leadership Values, Strategies, and Skills. The Finnish Journal of Business Economics, Winter, 46-63.

Davenport, T.H., \& Prusak, L., (1998). Working Knowledge: How Organizations Manage What They Know. Boston: Harvard Business School Press.

Evans, C., (2003). Managing for Knowledge: HR's Strategic Role. Butterworth-Heinemann, Amsterdam.

Garavan, T. N., (1991). Strategic human resource development. Journal of European Industrial Training, 15 (1), 17-31.

Garcia, H. (2006). Effective leadership response to crisis. Strategy and Leadership, 34 (1), 4-10.

Grant, R. M., (1996) Toward a knowledge-based theory of the firm. Strategic Management Journal, 17(Winter Special Issue), 109-122.

Grey, D., (1999). Knowledge Mapping: a practical overview. Smith Weaver Smith online article. Available at : http://www. smithweaversmith.com/knowledg2.htm.

Gupta, A. K., Govindarajan, V., (2000). Knowledge Flows within the Multinational Corporation. Strategic Management Journal, 21, $473-$ 496.

Guzzo, R. A., and Shea, G. P., (1992). Group performance and intergroup relations in organizations. In Handbook of Industrial and Organizational Psycholog. MD Dunnette, LM Hough, 3, 269-313. Palo Alto, CA: Consult. Psychol. Press. 2nd.

Hitt, M. A., Bierman, L., Shimizu, K., and Kochhar, R., (2001) Direct and moderating effects of human capital on strategy and performance in professional service firms: A resource-based perspective. Academy of Management Journal 44 (1), 13-28.

Hitt, M. A., Keats, B. A. \& DeMarie, S. M., (1998). Navigating in the new competitive landscape: Building strategic flexibility and competitive advantage in the 21st century. Academy of Management Executive, 12, 22-42.

James, E. H., \& Wooten, L. P., (2005). Leadership as (un) usual: How to display competence in times of crisis. Organizational Dynamics, 34(2), 141-152.

Jackson, S.E., \& Schuler, R.S., (2003). Managing human resources through strategic partnerships. (8th ed.) Mason, Ohio: Thomson Southwestern.

Lagadec, P., (1997). Learning Processes for Crisis Management in Complex Organizations. Journal of contingencies and crisis management, 5 (1), 24-31.

MacNeil, W., and Topping, K., (2007). Crisis management in schools: Evidence-based prevention. Journal of Educational Inquiry, 7 (1), 64-94.

McCracken, M., \& Wallace, M., (2000). Exploring strategic maturing in HRD and hyphen; rhetoric, aspiration or reality. Journal of European Training, 21 (8-9), 425-446.

Nurmi, R. W., and Darling, J. R., (1997). International Management Leadership: The Primary Competitive Advantage. New York, NY: International Business Press.

Olivera, F., (2000). Memory systems in organizations: An empirical investigation of mechanisms for knowledge collection, storage and access. Journal of Management Studies 37(6), 811-832.

Ouintas, P., Lefrere, P., and Jones, G., (1997). Knowledge management: a strategic agenda. Long Range Planning, 30 (3), 91-385.

Pearson, C., \& Clair, J., (1998). Reframing crisis management. Academy of Management Review, 23 (1), 59-76.

Quarantelli, E. L., (1988). Disaster studies: An analysis of the social historical factors affecting the development of research era. International Journal of Mass Emergencies and Disaster, 5, 285-310.

Roberts, K. H., Madsen, P., and Desai, V., (2007). Organizational Sense-Making during Crisis. In Pearson, C., Roux-Dufort, C., and Clair, J., (Eds.) The International Handbook of Organizational Crisis Management London: Sage, 107-122.

Ruona, W. E. A., Lynham, S. A., \& Chermack, T. J., (2003). Insights on emerging trends and the future of human resource development. Advances in Developing Human Resources, 5(3), 272-282.

Shelton, C. K., and Darling, J. R., (2001). Entrepreneurship in the Quantum Age: A New Set of Organizational Development Skills. The Academy of Entrepreneurship Journal, Winter, 45- 59.

Simon, L., \& Pauchant, T. C., (2000). Developing the three levels of learning in crisis management: a case study of the Hagersville Tire Fire. Review of Business, 21 (3/4), 6-11.

Teece, D. J., (1998). Capturing Value from Assets: The New Economy, Market, and Intangible Assets. California Management Review, 40, (3), 57-79. 
Tiwana, A., (2002). The Knowledge Management Toolkit: Orchestrating IT, Strategy, and Knowledge Platforms. Prentice Hall, Upper Saddle Rive.

Walsh, J. P., and Ungson, G. R., (1991). Organizational memory. Academy of Management Review, 16 (1), 57-91.

Weick, K. E., (1995). Sensemaking in Organizations. Thousand Oaks, CA: Sage.

Weick, K. E., \& Roberts, K. H., (1993). Collective mind in organizations: Heedful interrelating on flight decks. Administrative Science Quarterly, 38, 357-381.

Winkleman, M., (1999). The right stuff. Chief Executive, 14, 80-81.

Wooten, L. P., \& James, E. H., (2004). When firms fail to learn: The perpetuation of discrimination in the workplace. Journal of Management Inquiry, 13 (1), 23-33.

Zack, M., (1999), Developing a knowledge strategy. California management review, 41 (3), 125-145. 